\title{
Interannual variation in the epibenthic megafauna at the shallowest station of the HAUSGARTEN observatory $\left(79^{\circ} \mathrm{N}, 6^{\circ} \mathrm{E}\right)$
}

\author{
K. S. Meyer ${ }^{1}$, M. Bergmann ${ }^{2}$, and T. Soltwedel ${ }^{2}$ \\ ${ }^{1}$ Oregon Institute of Marine Biology, 63466 Boat Basin Road, Charleston, Oregon 97420, USA \\ ${ }^{2}$ HGF-MPG Group for Deep-Sea Ecology and Technology, Alfred Wegener Institute Helmholtz Centre for Polar and Marine \\ Research, Am Handelshafen 12, 27570 Bremerhaven, Germany \\ Correspondence to: K. Meyer (kimeyer@alumni.nmu.edu)
}

Received: 29 November 2012 - Published in Biogeosciences Discuss.: 13 December 2012

Revised: 27 February 2013 - Accepted: 23 April 2013 - Published: 3 June 2013

\begin{abstract}
Epibenthic megafauna play an important role in the deep-sea environment and contribute significantly to benthic biomass, but their population dynamics are still understudied. We used a towed deep-sea camera system to assess the population densities of epibenthic megafauna in 2002, 2007, and 2012 at the shallowest station (HG I, 1300 m) of the deep-sea observatory HAUSGARTEN, in the eastern Fram Strait. Our results indicate that the overall density of megafauna was significantly lower in 2007 than in 2002, but was significantly higher in 2012 , resulting in overall greater megafaunal density in 2012. Different species showed different patterns in population density, but the relative proportions of predator/scavengers and suspension-feeding individuals were both higher in 2012. Variations in megafaunal densities and proportions are likely due to variation in food input to the sea floor, which decreased slightly in the years preceding 2007 and was greatly elevated in the years preceding 2012. Both average evenness and diversity increased over the time period studied, which indicates that HG I may be foodlimited and subject to bottom-up control. The community of HG I may be unique in its response to elevated food input, which resulted in higher evenness and diversity in 2012.
\end{abstract}

\section{Introduction}

Epibenthic megafauna are defined as those organisms $>1 \mathrm{~cm}$ which inhabit the sediment-water interface, or are arbitrarily delineated as any organism which is visible with a camera (Bergmann et al., 2011a). Despite their comparatively low abundances, megafauna play an important role in the benthic community, exerting significant effects on bioturbation (Wheatcroft et al., 1989), carbon budgeting (Piepenburg, 2005), oxygen consumption (Piepenburg et al., 1995), and sediment composition (Gallucci et al., 2008b). Megafauna make up a large proportion of the biomass at the sedimentwater interface (Piepenburg et al., 1995) and enhance habitat complexity - both by virtue of their physical structure (Beaulieu, 2001) and by modifying the texture of the sediment with burrows, tracks, and traces (Wheatcroft et al., 1989; Kaufmann and Smith, 1997). Furthermore, through predation, megafauna control the population dynamics of smaller-sized prey and therefore shape benthic community composition (Gallucci et al., 2008a; Feder and Pearson, 1988; Sardá et al., 1998).

As a rule, megafauna are underrepresented in samples obtained with grabs or cores because of their low abundance and large size (Piepenburg et al., 1995). Sample collection by trawl is also not ideal because of damage to specimens and habitats and because it is not quantitative (Piepenburg et al., 1996b). On the other hand, image sampling of megafauna with a towed-camera system is highly useful because the organisms can be seen in their natural positions and there is no risk of specimen destruction. Randomly collected images can also be used to quantify organism abundances and thus enable characterization of the community. However, physical samples are needed for ground-truthing as most species cannot be identified from images alone.

In recent years, towed-camera studies have been undertaken in the Arctic at stations in the central Arctic (Gamber and Clark, 1978), Canadian Basin (MacDonald et al., 2010; Afanasév, 1978), north Alaska (Bluhm et al., 2005), 
Makarov Basin (Hunkins et al., 1960), the Alpha Ridge (Paul and Menzies, 1974), in the Greenland Sea (Jones et al., 2007; Mayer and Piepenburg, 1996; Schulz et al., 2010; Starmans and Gutt, 2002), in the Fram Strait (Bergmann et al., 2011b; Soltwedel et al., 2009) and Svalbard waters (Piepenburg et al., 1996a; Bergmann et al., 2011a).

However, despite these efforts, the megafauna of the deep sea remain largely understudied. There exists a present urgency to effectively characterize benthic communities and establish a base-line against which future changes can be tracked, especially in the Arctic, where recent years have seen decreases in perennial sea ice cover (Comiso et al., 2008; Kauker et al., 2009) and associated changes in megafaunal densities and community patterns are to be expected. Significant changes in the relative abundances of epibenthic megafaunal species on the scale of years to decades have already been observed in the northeast Pacific (Ruhl et al., 2008), the Fram Strait (Bergmann et al., 2011b), and the Porcupine Abyssal Plain (Billett et al., 2001, 2010). Such alterations were attributed by their respective authors to changes in food supply and environmental forcing, which may be related to long-term shifts in climate or decadal climate cycles. In the Fram Strait, there exists a chain-link relationship between water temperature, ice cover (BeszczynskaMöller et al. 2012), primary productivity, downward carbon export (Bauerfeind et al., 2009; Lalande et al., 2011), and abundance of benthic organisms (Schewe and Soltwedel, 2003; Bergmann et al. 2011b). A full discussion of this chain of reaction is outside the scope of this paper, but we focus on one aspect: the influence of food input to the seafloor, as indicated by biochemical condition of the sediment, on the epibenthic megafauna. Conversely, megafaunal organisms and their activities can alter the small-scale habitat structure and biochemical regime (Soltwedel and Vopel, 2001; Quéric and Soltwedel, 2007; Hasemann and Soltwedel, 2011).

The goal of the present study is to assess interannual changes in the benthic megafaunal community at the shallowest station of the HAUSGARTEN observatory in the eastern Fram Strait. More specifically, we describe differences in the megafaunal density and diversity over the time period 2002-2012, and how the benthic community may be influenced by biotic and abiotic environmental factors. This study also represents a contribution to the species inventory of the deep Fram Strait.

\section{Methods}

\subsection{Study area}

Sampling was conducted at the HAUSGARTEN station HG I (also Transect A in Soltwedel et al., 2009) at approximately $79^{\circ} 8^{\prime} \mathrm{N}, 6^{\circ} 0^{\prime} \mathrm{E}$, the easternmost and shallowest $(\sim 1300 \mathrm{~m})$ station of the HAUSGARTEN observatory, located in the eastern Fram Strait (Soltwedel et al., 2005). This long-term observatory, maintained for over a decade by the Alfred Wegener Institute Helmholtz Centre for Polar and Marine Research, provides a unique opportunity to study long-term dynamics in an area marked by exchange of Atlantic and Arctic water masses (Soltwedel et al., 2005). Though some stations of the HAUSGARTEN observatory experience seasonally varying ice conditions, HG I is primarily influenced by Atlantic water and thus generally not covered by ice at any time during the year because of its easterly location.

\subsection{Sampling procedures}

Photographic samples of the seafloor at HG I were collected during the expeditions ARK-XVIII/1 (2002), ARK-XXII/2 (2007), and ARK-XXVII/2 (2012) of the German ice-breaker $\mathrm{R} / \mathrm{V}$ Polarstern. Still images were collected in situ using a vertically facing towed camera system, the Ocean Floor Observation System (OFOS). The OFOS was towed for $3-5 \mathrm{~h}$ at approximately 0.5 knots along a transect of the seafloor. The actual start and end points as well as the length of the transects varied slightly from year to year, though the spatial variation was small (5.5 nautical miles between the start and end points which lie the furthest apart) and all photographs were taken at comparable depths (1274-1325 m, Fig. 1, Table 1). The OFOS was towed at an altitude of approximately $1.5 \mathrm{~m}$. The altitude was controlled by the winch operator, who relied on video feed from the OFOS camera. In 2002 and 2007, altitude was indicated by the position of a fore-runner weight, and in 2012, altitude was measured directly by an altimeter on the OFOS frame and displayed on the screen.

In 2002 , the OFOS frame $(145 \mathrm{~cm} \times 225 \mathrm{~cm} \times 145 \mathrm{~cm})$ was equipped with a still camera (Benthos Inc.) and a black and white video camera (Deep-Sea Power and Light), two high-intensity discharge lights of $250 \mathrm{~W}$ each, strobes $\left(600 \mathrm{~W} \mathrm{~s}^{-1}\right)$ and three red laser points. These lights were aligned parallel to each other at an angle of $90^{\circ}$ to the seafloor, assuming the seafloor was flat. Energy was provided by two lead storage batteries. The red laser pointers were fixed vertically on each OFOS frame at a distance of $50 \mathrm{~cm}$ apart and served as a size reference for the photographed area. In 2007, the frame of a slightly modified OFOS $(120 \mathrm{~cm} \times 110 \mathrm{~cm} \times 120 \mathrm{~cm})$ was equipped with a still (Benthos model 372-A) and a black and white video camera (OKTOPUS, Germany), two green laser pointers (Scholz) at a distance of $52 \mathrm{~cm}$ to each other for size reference, telemetry (AdiTech-Koax), forerunner weight, 2 xenon head lamps (OKTOPUS) and 2 flash lights (BENTHOS flash, model 383). In both 2002 and 2007, an aperture of 5.6 and a double flash $(600 \mathrm{~W})$ were used, and the still camera was loaded with a 30 m Kodak Ektachrome 100 ASA film, allowing r800 exposures. In 2012, a completely newly designed OFOS was equipped with a Canon camera (EOS-1Ds Mark III, modified for underwater applications by iSiTEC GmbH, Germany), a strobe (Kongsberg 0E11-242), four LED lights (LED Multi-Sealite, DeepSea Power and 
Table 1. Summary of gear deployments conducted at HG I. (MUC) multiple corer, (OFOS) Ocean Floor Observation System, (AGT) Agassiz trawl, (GBC) giant box core.

\begin{tabular}{llllll}
\hline Station no. & Date (dd-month-yy) & Latitude & Longitude & Depth (m) & Gear \\
\hline PS 59/91 & 12-Jul-01 & $79^{\circ} 7.98^{\prime} \mathrm{N}$ & $6^{\circ} 04.50^{\prime} \mathrm{E}$ & 1284 & MUC \\
PS 62/171-2 & 6-Aug-02 & $79^{\circ} 8.46^{\prime} \mathrm{N}$ & $6^{\circ} 5.52^{\prime} \mathrm{E}$ & 1292 & MUC \\
PS 62/191-1 & 10-Aug-02 & $79^{\circ} 08.80^{\prime} \mathrm{N}$ & $5^{\circ} 59.66^{\prime} \mathrm{E}$ & 1299 & OFOS start \\
& & $79^{\circ} 08.03^{\prime} \mathrm{N}$ & $5^{\circ} 46.52^{\prime} \mathrm{E}$ & 1325 & OFOS end \\
PS 64/402-1 & 21-Jul-03 & $79^{\circ} 7.98^{\prime} \mathrm{N}$ & $6^{\circ} 5.52^{\prime} \mathrm{E}$ & 1277 & MUC \\
PS 66/103-1 & 7-Jul-04 & $79^{\circ} 08.97^{\prime} \mathrm{N}$ & $5^{\circ} 56.35^{\prime} \mathrm{E}$ & 1323 & AGT \\
PS 66/104-1 & 7-Jul-04 & $79^{\circ} 7.99^{\prime} \mathrm{N}$ & $6^{\circ} 5.46^{\prime} \mathrm{E}$ & 1281 & MUC \\
PS 68/277-2 & 26-Aug-05 & $79^{\circ} 8.00^{\prime} \mathrm{N}$ & $6^{\circ} 5.57^{\prime} \mathrm{E}$ & 1279 & MUC \\
MSM2-4/773-1 & 22-Aug-06 & $79^{\circ} 8.00^{\prime} \mathrm{N}$ & $6^{\circ} 5.42^{\prime} \mathrm{E}$ & 1257 & MUC \\
PS 70/163-1 & 12-Jul-07 & $79^{\circ} 8.07^{\prime} \mathrm{N}$ & $5^{\circ} 59.40^{\prime} \mathrm{E}$ & 1304 & MUC \\
PS70/189-1 & 16-Jul-07 & $79^{\circ} 7.93^{\prime} \mathrm{N}$ & $6^{\circ} 5.26^{\prime} \mathrm{E}$ & 1290 & GBC \\
PS 70/207-1 & 18-Jul-07 & $79^{\circ} 07.97^{\prime} \mathrm{N}$ & $5^{\circ} 59.62^{\prime} \mathrm{E}$ & 1299 & OFOS start \\
& & $79^{\circ} 08.04^{\prime} \mathrm{N}$ & $5^{\circ} 46.40^{\prime} \mathrm{E}$ & 1322 & OFOS end \\
PS 72/137-2 & 12-Jul-08 & $79^{\circ} 8.07^{\prime} \mathrm{N}$ & $6^{\circ} 5.51^{\prime} \mathrm{E}$ & 1281 & MUC \\
PS72/137-5 & 12-Jul-08 & $79^{\circ} 7.75^{\prime} \mathrm{N}$ & $6^{\circ} 7.46^{\prime} \mathrm{E}$ & 1273 & AGT \\
PS 74/109-2 & 13-Jul-09 & $79^{\circ} 8.07^{\prime} \mathrm{N}$ & $6^{\circ} 5.74^{\prime} \mathrm{E}$ & 1285 & MUC \\
PS 76/132-2 & 6-Jul-10 & $79^{\circ} 8.16^{\prime} \mathrm{N}$ & $6^{\circ} 6.35^{\prime} \mathrm{E}$ & 1283 & MUC \\
PS 78/140-6 & 14-Jul-11 & $79^{\circ} 8.11^{\prime} \mathrm{N}$ & $6^{\circ} 6.27^{\prime} \mathrm{E}$ & 1283 & MUC \\
PS 80/168-1 & 17-Jul-12 & $79^{\circ} 07.94^{\prime} \mathrm{N}$ & $6^{\circ} 15.70^{\prime} \mathrm{E}$ & 1321 & OFOS start \\
PS 80/168-6 & 18-Jul-12 & $79^{\circ} 8.00^{\prime} \mathrm{N}$ & $6^{\circ} 07.84^{\prime} \mathrm{E}$ & 1274 & OFOS end \\
\hline
\end{tabular}

Light), telemetry (LRT-400 Fiber, iSiTEC), and three red laser points (OKTOPUS), positioned $50 \mathrm{~cm}$ apart from each other. The still camera of each OFOS was mounted on the frame in a vertical position to the sea floor and was triggered automatically every $30 \mathrm{~s}$ to minimize spatial overlap of images. Additional manually triggered images were taken when features of particular interest occurred in the viewfinder.

Physical specimens of observed species were obtained using an Agassiz trawl (20 mm mesh) in 2004, 2008 and 2012 and a box core in 2007 (Table 1) to enable "groundtruthing" (taxonomic identification). Taxa were identified by taxonomic experts (see Acknowledgments) either by examination of physical samples or from photographs available on the web-based image database BIIGLE (see below).

\subsection{Image analysis}

All images were analyzed and stored using the image analysis program and database BIIGLE (Bio-Image Indexing, Graphic Labelling, and Exploration) web-2.0, which can be accessed from any standard web browser (www.BIIGLE.de) (Bergmann et al., 2011a; Ontrup et al., 2009). BIIGLE also serves as a semi-automatic taxon identification system, though in this study, all taxa were identified manually. The laser points present in each image were detected by a computer algorithm and used as a standard to calculate the surface area of each image, which could then be used to convert species abundances to densities. In 2002 and 2007 images, the surface area of each image was used as a proxy for altitude because altitude was not measured directly. Images that were within the most common surface area or altitude range (2002 and 2007: 3.3-4.1 $\mathrm{m}^{2} ; 2012: 1.3-1.5 \mathrm{~m}$ altitude) were recorded automatically, and those that were not unusually bright or dark were eligible for analysis. Each transect was split into three equal segments represented by three equal groups of statistically recorded images, and the first 30 randomly selected eligible images from each segment of each transect were used for analysis. Because there was no visible overlap in content, each image was treated as a replicate sample (MacDonald et al., 2010; Bergmann et al., 2011a, b).

To label taxa and habitat features in BIIGLE, the working species name was selected from a drop-down list and pinned to the feature by clicking on its location in the image. Image labelling was completed in a shaded room using a 19-20" computer monitor connected to a PC. All images were investigated using the maximum available zoom in BIIGLE, and all observable biota and biotic habitat features were labelled. To eliminate practice effects, each image underwent one or more "quality checks," in which the image was re-examined for accuracy and thoroughness of taxa identification. Image analysis was completed by the same individual to avoid interpersonal effects (Schoening et al., 2012).

\subsection{Environmental parameters}

Benthic environmental parameters were determined from sediment samples obtained by a multiple corer during annual research expeditions between 2001 and 2011 aboard the 


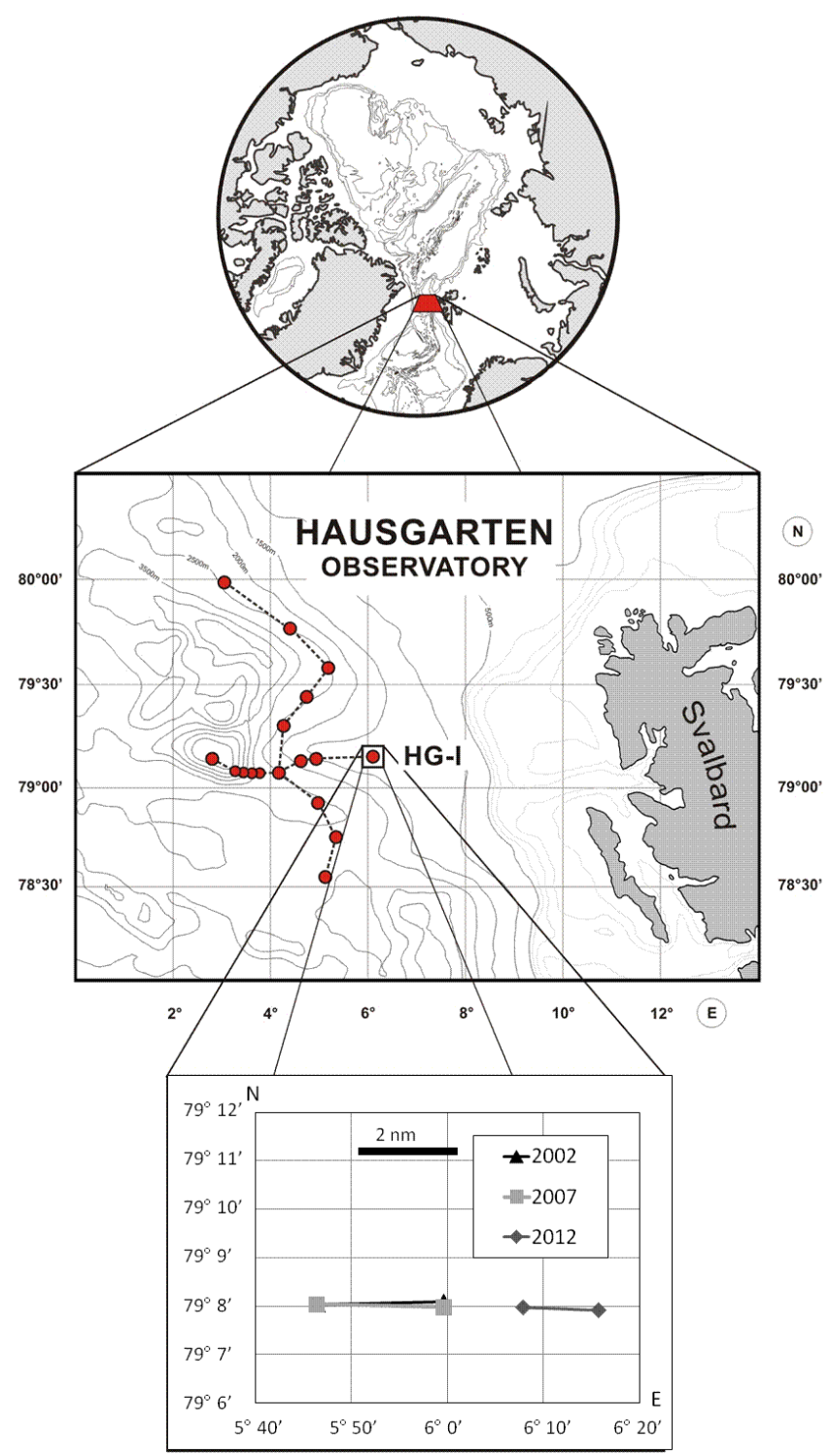

Fig. 1. Location of OFOS transects at HAUSGARTEN I sampled in 2002, 2007, and 2012.

research vessels Polarstern and Maria S. Merian. The top centimetres of sediment were sub-sampled using syringes $(1 \mathrm{~cm}$ in diameter) with the tips cut off and analyzed for particulate protein and chloroplastic pigment content. Sedimentbound particulate proteins, indicating the biomass of small organisms and detrital matter, were determined by photometry. Chloroplastic pigments, indicating phytodetritus (food) at the seafloor, were extracted in $90 \%$ acetone and measured with a Turner fluorometer (Shuman and Lorenzen, 1975).

\subsection{Data analysis}

For data analysis, we focused on eleven species which were large enough to be reliably recognized in all photographs taken by the different camera systems. Species counts in each image were converted to densities using area estimates for each image. Densities of habitat features such as worm tubes, "white debris", and Lebensspuren were also recorded, and diversity indices (species richness (total species $\mathrm{m}^{-2}$ ), Pielou's evenness (Pielou, 1969), Shannon-Wiener diversity (Shannon and Weaver, 1963)) for each image were calculated with the software Primer v6 (Clarke and Gorley, 2006). Comparisons of species densities, habitat feature densities, and diversity indices between years were carried out using (non-)parametric analysis of variance in SPSS (IBM, USA). A Levene's test was used to test homogeneity of variance. In the instance that a $\log (x+1)$ transformation ensured equal variance, an ANOVA test on $\log (x+1)$-transformed data was used, and post-hoc Bonferroni tests showed differences between pairs of years. For cases of unequal variance, pairwise differences between the years were discerned using Mann-Whitney $U$ tests with a Bonferroni correction of $p=0.05 / 3$ comparisons $=0.017$. Species-accumulation curves were constructed for each year using Primer to determine the number of images necessary to sufficiently sample the 11 most reliably identified species.

Multivariate statistics based on a Bray-Curtis similarity matrix were carried out in Primer to determine differences in the biological community between years. Species density data were square-root transformed to reduce the effects of overly dominant species. A 2-way nested ANOSIM design was used to test for differences between transect segments and between years, and a non-metric multidimensional scaling (MDS) ordination plot was constructed to visualize these differences. Using a SIMPER routine, we also determined "character species" for each year, which we define as those species which together contribute $90 \%$ of the average similarity within images from a particular year. For each year, species were grouped by mobility (vagile or sessile, as inferred from the images) and trophic group according to the results of Bergmann et al. (2009) and information from taxonomic experts to assess differences in the relative dominance of these groups between years.

\section{Results}

\subsection{Image labelling}

Altogether, 270 images were analyzed (90 from each year), representing a total area of $767.92 \mathrm{~m}^{2}$ of the sea floor $\left(281.14 \mathrm{~m}^{2}\right.$ in $2002 ; 253.26 \mathrm{~m}^{2}$ in 2007 ; and $238.58 \mathrm{~m}^{2}$ in 2012). The average area per image was $3.12 \pm 0.21 \mathrm{~m}^{2}$ in $2002,2.85 \pm 0.16 \mathrm{~m}^{2}$ in 2007 , and $2.65 \pm 0.06 \mathrm{~m}^{2}$ in 2012 (mean \pm standard error).

A total of 20 (putative) species and four habitat features were identified from the images at HG I (Table 2). Of these, only the 11 taxa which were most reliably recognizable were used for statistical analysis; all results from here on are 


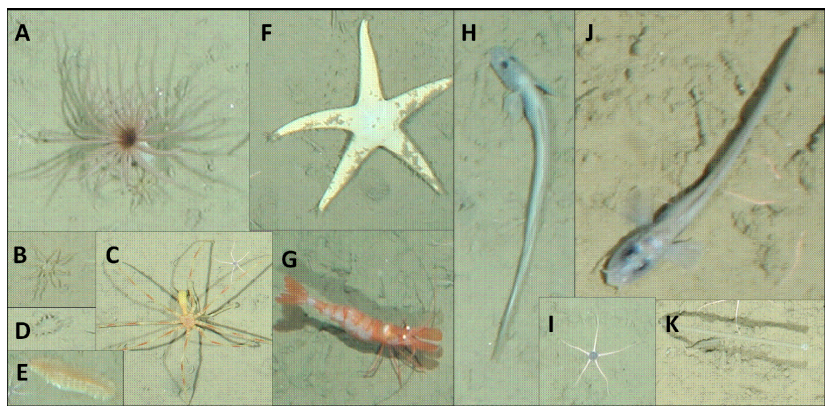

Fig. 2. Taxa found at station HG I. (A) purple cerianthid; (B) cf. Nymphon macronyx; (C) Colossendeis proboscidea; (D) Elpidia sp.; (E) Bylgides sp.; (F) Bathybiaster vexillifer; (G) Bythocaris cf. leucopis; (H) Lycodonus flagellicauda; (I) Ophiocten gracilis; (J) Lycodes squamiventer; (K) Jasmineira schaudinni. Scale bar $=10 \mathrm{~cm},(\mathbf{A}-\mathbf{B}),(\mathbf{D}-\mathbf{K}) ; 5 \mathrm{~cm},(\mathbf{C})$.

reported for these 11 taxa (Fig. 2, Table 2). Four habitat features (see below) were also tested for variations in mean density between years.

Permutated species-accumulation curves showed an asymptotic leveling after approximately 40 images in each sampling year, so it was assumed that sampling was sufficient to accurately document the presence of the 11 most recognizable species in these years (Fig. 3).

\subsection{Differences between years}

The 2-way nested ANOSIM test showed that segments of each transect were significantly similar $(R=0.141$, $p=0.001$ ), but different years were significantly different $(R=0.909, p=0.004)$. Because there was significant similarity between transect segments, all further multivariate analyses were conducted with respect to year only, with no division between transect segments.

To visualize differences in the benthic community between years, a MDS (non-metric multidimensional scaling) ordination plot was constructed (Fig. 4). It appears from the constructed MDS plot that images from different years form visually coherent groups of data points; there is significant overlap between points from 2002 and 2007, and 2012 is more different from these years than they are from each other. Also, 2007 is the year with the highest inter-image variability, represented by a wider spacing of the points on the MDS plot (Fig. 4). A stress value of 0.12 indicates a good 2-D representation of the data.

The mean total megafaunal density was $19.6 \pm 0.4$ ind. $\mathrm{m}^{-2}$ in $2002,17.2 \pm 0.4$ ind. $\mathrm{m}^{-2}$ in 2007 , and $54.8 \pm 1.0$ ind. $\mathrm{m}^{-2}$ in 2012. These means indicate lower overall faunal density in 2007 than 2002 and higher faunal density in 2012 than 2007, which resulted in overall higher faunal density in 2012 than 2002 (Fig. 5). All differences between years are statistically significant (Table 2).

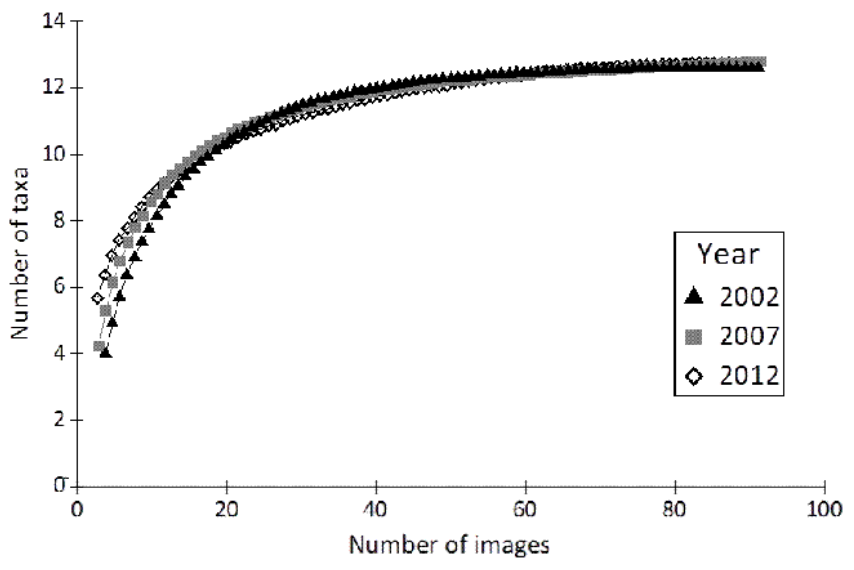

Fig. 3. Permutated species-accumulation curves based on documentation of the 11 most recognizable species at HG I. An asymptote appears to be reached in each year.

The densities of six of the 11 analyzed taxa showed no significant differences between years; these include "purple cerianthid", Bylgides sp., Colossendeis probiscidea, Bythocaris cf. leucopis, Bathybiaster vexillifer, and Lycodes squamiventer (Kruskal-Wallis (K-W) or ANOVA, $p>0.05$; Table 2). The eelpout Lycodonus flagellicauda stayed at relatively constant density, the only significant difference being a decrease from 2002 to 2007 that fell right on the cut-off for statistical significance (post-hoc pair-wise Mann-Whitney test $(\mathrm{M}-\mathrm{W}), U=3736, p=0.017)$. The density of the pycnogonid cf. Nymphon macronyx increased from 2002 to 2012 with significant differences between each pair of tested years $\left(\mathrm{K}-\mathrm{W}, \mathrm{d} f=2, \chi^{2}=219, p<0.001\right)$. The tube-building polychaete Jasmineira schaudinni had a much higher density in 2012 than in 2007, with statistically significant differences between the year pairs 2002-2012 and 2007-2012 $\left(\mathrm{K}-\mathrm{W}, \mathrm{d} f=2, \chi^{2}=175, p<0.001\right.$; Table 2). The same pattern was observed for the holothurian Elpidia sp., which had much higher density in $2012\left(\mathrm{~K}-\mathrm{W}, \mathrm{df}=2, \chi^{2}=25\right.$, $\mathrm{p}<0.001$; Table 2). Population density of the ophiuroid Ophiocten gracilis decreased from 2002-2007 and then increased from 2007 to 2012, leading to an overall higher density in 2012 than in $2002\left(\mathrm{~K}-\mathrm{W}, \mathrm{d} f=2, \chi^{2}=190\right.$, $p<0.001$; Table 2)

Results of the SIMPER routine helped to identify "character species", which defined the community in each year. An average similarity of $84.2 \%$ was found between images in 2002, along with $81.2 \%$ average similarity between images in 2007, and $88.2 \%$ average similarity between images in 2012. In 2002, 2007, and 2012, the largest percent contribution to within-year similarity was made by the brittle star $O$. gracilis (2002: 96.4\%, 2007: 94.8\%, 2012: 71.3\%). In 2012, other species also contributed to the within-year similarity, and these included cf. $N$. macronyx $(17.6 \%)$ and J. schaudinni (10.0\%). 
Table 2. Mean densities (ind. $\mathrm{m}^{-2}$ ) of megafaunal taxa recorded from images in 2002, 2007, and 2012 at HG I. The presence of other species collected from bottom samples is indicated (no numbers given). Asterisk denotes the 11 taxa which were reliably recognized and were used in statistical analyses. Abbreviations as in Table 1, plus the following: (SF) suspension feeder, (P/S) predator/scavenger, (DF) deposit feeder.

\begin{tabular}{|c|c|c|c|c|c|c|c|c|c|c|c|c|c|c|}
\hline \multirow{2}{*}{$\begin{array}{l}\text { Species/Taxon } \\
\text { Demospongiae }\end{array}$} & \multirow{3}{*}{$\begin{array}{l}\begin{array}{l}\text { Sampling } \\
\text { gear }\end{array} \\
\text { AGT }\end{array}$} & \multirow{3}{*}{$\begin{array}{l}\text { Station No. } \\
\text { PS80/168-6 }\end{array}$} & \multirow[t]{3}{*}{$\begin{array}{r}\text { Feeding } \\
\text { mode }\end{array}$} & \multirow[t]{3}{*}{ Mobility } & \multicolumn{2}{|c|}{$\begin{array}{c}2002 \\
\text { Mean } \pm \text { SEM }\end{array}$} & \multicolumn{2}{|c|}{$\begin{array}{c}2007 \\
\text { Mean } \pm \text { SEM }\end{array}$} & \multicolumn{2}{|c|}{$\begin{array}{c}2012 \\
\text { Mean } \pm \text { SEM }\end{array}$} & \multirow[t]{2}{*}{ Test used } & \multirow[t]{2}{*}{$f$ or $\chi 2$} & \multirow[t]{2}{*}{$p$} & $\begin{array}{r}\text { Significant } \\
\text { difference }\end{array}$ \\
\hline & & & & & & & & & & & & & & \\
\hline $\begin{array}{l}\text { Tentorium } \\
\text { semisuberites }\end{array}$ & & & & & & & & & & & & & & \\
\hline Cnidaria & & & & & & & & & & & & & & \\
\hline Purple cerianthid* & OFOS & & SF & Sessile & 0.01 & 0.01 & 0.03 & 0.01 & 0.05 & 0.01 & $\mathrm{~K}-\mathrm{W}, \mathrm{M}-\mathrm{W}$ & 4.87 & 0.09 & no differences \\
\hline White anemone & OFOS & & SF & Sessile & & & & & & & & & & \\
\hline Hormathiidae & AGT & PS80/168-6 & & & & & & & & & & & & \\
\hline Stegopoma plicatile & AGT & PS66/103-1 & & & & & & & & & & & & \\
\hline Mollusca & & & & & & & & & & & & & & \\
\hline Mohnia sp. & AGT, OFOS & PS80/168-6 & $\mathrm{P} / \mathrm{S}$ & & & & & & & & & & & \\
\hline Bathyarca frielei & AGT, OFOS & PS80/168-6 & $\mathrm{SF}$ & Sessile & & & & & & & & & & \\
\hline Thyasira dunbari & AGT & PS72/137-5 & & & & & & & & & & & & \\
\hline Yoldiella propinqua & AGT & PS72/137-5 & & & & & & & & & & & & \\
\hline Yoldiella annenkovae & AGT & PS72/137-5 & & & & & & & & & & & & \\
\hline Alvania wyvillethomsoni & AGT & PS72/137-5 & & & & & & & & & & & & \\
\hline Oenopota sp. & AGT & PS72/137-5 & & & & & & & & & & & & \\
\hline Siphonodentalium laubieri & AGT & PS66/103-1 & & & & & & & & & & & & \\
\hline Chaetoderma nitidulum & AGT & PS72/137-5 & & & & & & & & & & & & \\
\hline Pycnogonida & & & & & & & & & & & & & & \\
\hline Colossendeis proboscidea $*$ & OFOS, AGT & PS66/103-1 & DF & Vagile & 0.01 & 0.01 & 0.01 & 0.01 & 0.01 & 0.01 & ANOVA & 0.27 & 0.77 & no differences \\
\hline cf. Nymphon macronyx* & OFOS, AGT & PS72/137-5 & $\mathrm{P} / \mathrm{S}$ & Vagile & 0.01 & 0.01 & 0.30 & 0.04 & 3.45 & 0.14 & $\mathrm{~K}-\mathrm{W}, \mathrm{M}-\mathrm{W}$ & 219 & 0 & $2002<2007<2012$ \\
\hline Sipuncula & & & & & & & & & & & & & & \\
\hline $\begin{array}{l}\text { Nephasoma diaphanes } \\
\text { diaphanes }\end{array}$ & AGT & PS72/137-5 & & & & & & & & & & & & \\
\hline Nephasoma lilljeborgi & $\mathrm{GBC}$ & PS70/189-1 & & & & & & & & & & & & \\
\hline Echiura & & & & & & & & & & & & & & \\
\hline Hamingia arctica & AGT & PS66/103-1 & & & & & & & & & & & & \\
\hline Annelida & & & & & & & & & & & & & & \\
\hline Jasminiera schaudinni $*$ & OFOS, AGT & PS72/137-5 & SF & Sessile & 0.17 & 0.02 & 0.10 & 0.02 & 1.42 & 0.79 & $\mathrm{~K}-\mathrm{W}, \mathrm{M}-\mathrm{W}$ & 175.4 & 0 & $\begin{array}{r}2002>2007 \\
2002<2012 \\
2007<2012\end{array}$ \\
\hline Thin tube worm & OFOS & & & & & & & & & & & & & \\
\hline Bylgides sp.* & OFOS & & $\mathrm{P} / \mathrm{S}$ & Vagile & 0.06 & 0.01 & 0.09 & 0.02 & 0.07 & 0.02 & $\mathrm{~K}-\mathrm{W}, \mathrm{M}-\mathrm{W}$ & 3.19 & 0.20 & no differences \\
\hline Abyssoninoe sp. & AGT & PS72/137-5 & & & & & & & & & & & & \\
\hline Axionice maculata & AGT & PS66/103-1 & & & & & & & & & & & & \\
\hline Chone sp. & AGT & PS72/137-5 & & & & & & & & & & & & \\
\hline Glyphanostomum pallescens & AGT & PS66/103-1 & & & & & & & & & & & & \\
\hline Laonice cirrata & AGT & PS72/137-5 & & & & & & & & & & & & \\
\hline Lumbrinereidae & AGT & PS80/168-6 & & & & & & & & & & & & \\
\hline Maldane arctica & AGT & PS66/103-1 & & & & & & & & & & & & \\
\hline Myriochele fragilis & AGT & PS66/103-1 & & & & & & & & & & & & \\
\hline Myriochele heeri & AGT & PS66/103-1 & & & & & & & & & & & & \\
\hline Myriochele cf. Oculata & AGT & PS66/103-1 & & & & & & & & & & & & \\
\hline Ophelina abranchiata & AGT & PS72/137-5 & & & & & & & & & & & & \\
\hline Polyphysia sp. & AGT & PS80/168-6 & & & & & & & & & & & & \\
\hline Praxillura longissima & AGT & PS66/103-1 & & & & & & & & & & & & \\
\hline Prinospio cirrifera & AGT & PS72/137-5 & & & & & & & & & & & & \\
\hline Siboglinidae & AGT & PS80/168-6 & & & & & & & & & & & & \\
\hline Crustacea & & & & & & & & & & & & & & \\
\hline Bythocaris cf. leucopis* & OFOS, AGT & PS66/103-1 & $\mathrm{P} / \mathrm{S}$ & Vagile & 0.02 & 0.01 & 0.02 & 0.01 & 0.02 & 0.01 & ANOVA & 0.16 & 0.85 & no differences \\
\hline Small white isopod, cf. Munnopsidae & OFOS & & & & & & & & & & & & & \\
\hline Halirages sp. & OFOS, AGT & PS80/168-6 & $\mathrm{P} / \mathrm{S}$ & & & & & & & & & & & \\
\hline Unciola sp. & AGT & PS72/137-5 & & & & & & & & & & & & \\
\hline Haploops setosa & AGT & PS72/137-5 & & & & & & & & & & & & \\
\hline Harpinia abyssi & GBC, AGT & PS70/189-1 & & & & & & & & & & & & \\
\hline Unciola cf. petalocera & GBC & PS70/189-1 & & & & & & & & & & & & \\
\hline Byblis minuticornis & AGT & PS72/137-5 & & & & & & & & & & & & \\
\hline Onisimus cf. leucopis & GBC & PS70/189-1 & & & & & & & & & & & & \\
\hline Anonyx nugax & AGT & PS66/103-1 & & & & & & & & & & & & \\
\hline Ischyrocerus brevicornis & AGT & PS72/137-5 & & & & & & & & & & & & \\
\hline Paranarthrurella voeringi & AGT & PS66/103-1 & & & & & & & & & & & & \\
\hline Pseudosphyrapus anomalus & AGT & PS66/103-1 & & & & & & & & & & & & \\
\hline Diastylis lepechini & AGT & PS66/103-1 & & & & & & & & & & & & \\
\hline Diastylis sp.1 near glabra & AGT & PS66/103-1 & & & & & & & & & & & & \\
\hline Eurycope cf. producta & AGT & PS72/137-5 & & & & & & & & & & & & \\
\hline
\end{tabular}


Table 2. Continued.

\begin{tabular}{|c|c|c|c|c|c|c|c|c|c|c|c|c|c|c|}
\hline \multicolumn{15}{|l|}{ Echinodermata } \\
\hline Bathybiaster vexillifer* & OFOS, AGT & PS66/103-1 & $\mathrm{P} / \mathrm{S}$ & Vagile & 0.03 & 0.01 & 0.04 & 0.01 & 0.05 & 0.01 & ANOVA & 0.50 & 0.61 & no differences \\
\hline Ophiocten gracilis* & OFOS, AGT & PS66/103-1 & $\mathrm{DF}$ & Vagile & 19.22 & 0.04 & 16.53 & 0.04 & 49.59 & 0.10 & $\mathrm{~K}-\mathrm{W}, \mathrm{M}-\mathrm{W}$ & 190 & 0 & $\begin{aligned} 2002>2007,2002<2012, \\
2007<2012\end{aligned}$ \\
\hline $\begin{array}{l}\text { Elpidia sp. * } \\
\text { Crinoid }\end{array}$ & $\begin{array}{l}\text { OFOS, AGT } \\
\text { OFOS }\end{array}$ & PS80/168-6 & $\begin{array}{l}\text { DF } \\
\text { SF }\end{array}$ & Vagile & 0.05 & 0.01 & 0.05 & 0.02 & 0.17 & 0.03 & $\mathrm{~K}-\mathrm{W}, \mathrm{M}-\mathrm{W}$ & 25 & 0 & $2002<2012,2007<2012$ \\
\hline \multicolumn{15}{|l|}{ Vertebrata } \\
\hline Lycodes squamiventer $*$ & OFOS, AGT & PS66/103-1 & $\mathrm{P} / \mathrm{S}$ & Vagile & 0.04 & 0.01 & 0.02 & 0.01 & 0.01 & 0.01 & $\mathrm{~K}-\mathrm{W}, \mathrm{M}-\mathrm{W}$ & 5.17 & 0.08 & no differences \\
\hline Lycodonus flagellicauda $*$ & OFOS, AGT & PS66/103-1 & $\mathrm{P} / \mathrm{S}$ & Vagile & 0.03 & 0.01 & 0.00 & 0.00 & 0.01 & 0.01 & $\mathrm{~K}-\mathrm{W}, \mathrm{M}-\mathrm{W}$ & 7.89 & 0.02 & $2002>2007$ \\
\hline Lycodes frigidus & AGT & PS80/168-6 & & & & & & & & & & & & \\
\hline Gaidropsarus argentatus & AGT & PS66/103-1 & & & & & & & & & & & & \\
\hline Amblyraja hyperborea & AGT & PS66/103-1 & & & & & & & & & & & & \\
\hline \multicolumn{15}{|l|}{ Other observed taxa } \\
\hline Chaetognatha & OFOS & & & & & & & & & & & & & \\
\hline Ctenophora & OFOS & & & & & & & & & & & & & \\
\hline \multicolumn{15}{|l|}{ Habitat features } \\
\hline Upright worm tubes & OFOS & & & & 10.34 & 0.36 & 3.49 & 0.42 & 15.01 & 0.60 & K-W, M-W & 147 & 0 & $\begin{array}{r}2002>2007,2002<2012, \\
2007<2012\end{array}$ \\
\hline Worm tube on sediment & OFOS & & & & 5.27 & 0.22 & 8.54 & 0.47 & 49.54 & 1.82 & $\mathrm{~K}-\mathrm{W}, \mathrm{M}-\mathrm{W}$ & 194 & 0 & $\begin{array}{r}2002>2007,2002<2012, \\
2007<2012\end{array}$ \\
\hline Lebensspuren & OFOS & & & & 2.26 & 0.12 & 1.32 & 0.08 & 0.30 & 0.05 & $\begin{array}{r}\text { ANOVA } \\
{[\log (x+1) \text { of data }]}\end{array}$ & 184 & 0 & $2002>2007>2012$ \\
\hline White debris & OFOS & & & & 0.16 & 0.03 & 0.08 & 0.02 & 1.37 & 0.10 & $\mathrm{~K}-\mathrm{W}, \mathrm{M}-\mathrm{W}$ & 176 & 0 & $\begin{array}{r}2002<2012 \\
2007<2012\end{array}$ \\
\hline \multicolumn{15}{|l|}{ Biodiversity indices } \\
\hline Pielou's evenness & & & & & 0.12 & 0.01 & 0.16 & 0.01 & 0.30 & 0.01 & $\mathrm{~K}-\mathrm{W}, \mathrm{M}-\mathrm{W}$ & 129 & 0 & $2002<2007<2012$ \\
\hline Shannon-Wiener diversity & & & & & 0.11 & 0.01 & 0.17 & 0.02 & 0.39 & 0.01 & $\mathrm{~K}-\mathrm{W}, \mathrm{M}-\mathrm{W}$ & 139 & 0 & $2002<2007<2012$ \\
\hline Total species $\mathrm{m}^{-2}$ & & & & & 2.23 & 0.10 & 2.43 & 0.13 & 3.87 & 0.09 & $\mathrm{~K}-\mathrm{W}, \mathrm{M}-\mathrm{W}$ & 100 & 0 & $2002<2012,2007<2012$ \\
\hline Total individuals $\mathrm{m}^{-2}$ & & & & & 19.64 & 0.41 & 17.20 & 0.38 & 54.85 & 0.98 & $\begin{array}{r}\text { ANOVA } \\
{[\log (x+1) \text { of data }]}\end{array}$ & 818 & 0 & $\begin{array}{c}2002>2007 \\
2002<2012 \\
2007<2012\end{array}$ \\
\hline
\end{tabular}

Both Pielou's evenness and Shannon-Wiener diversity increased over the time period studied, and differences between each pair of years were significant (evenness, $\mathrm{K}-\mathrm{W}, \mathrm{d} f=2$, $\chi^{2}=129, p<0.001$; Diversity, $\mathrm{K}-\mathrm{W}, \mathrm{d} f=2, \chi^{2}=139$, $p<0.001)$. Species richness, measured as the number of taxa $\mathrm{m}^{-2}$, was significantly higher in 2012 than in other years $\left(\mathrm{K}-\mathrm{W}, \mathrm{d} f=2, \chi^{2}=100, p<0.001\right)$.

\subsection{Mobility of fauna and trophic groups}

The benthic megafaunal community of HG I can be characterized as overwhelmingly vagile. Nine of the 11 species included in analysis, consisting of over $99 \%$ of observed individuals (97.3\% in 2012), are vagile, the only exceptions being the polychaete $J$. schaudinni and the "purple cerianthid." The majority of observed individuals could also be categorized as deposit feeders, and this group accounted for over $90 \%$ of the fauna. The average density of deposit feeders was lower in $2007\left(16.6 \pm 0.4 \mathrm{~m}^{-2}\right)$ than in 2002 $\left(19.3 \pm 0.4 \mathrm{~m}^{-2}\right)$ but much higher in $2012\left(49.8 \pm 1.0 \mathrm{~m}^{-2}\right)$. The relative proportion of deposit feeders decreased over the time period studied, from $98.2 \%$ in 2002 to $96.3 \%$ in 2007 to $90.7 \%$ in 2012 . The second most significant trophic group was predator/scavengers, which accounted for $0.9-6.6 \%$ of the fauna and increased in proportion over time. The proportion of suspension feeders also increased, from $0.6 \%$ in 2002 and 2007 to $2.5 \%$ of individuals in 2012, and this pattern was most likely due to increases in the density of $J$. schaudinni (Fig. 5). Though our analysis included only those 11 species which were large enough to be reliably recognized in images, this group comprises the vast majority of the megafauna present at HG I and can be used to make generalizations about trophic structure. In fact, only two megafaunal species of any significant density were excluded from analysis because they were only visible in images from 2012. These species include a sabellid polychaete and the bivalve Bathyarca freilei (see below). If both these species, which are most likely suspension feeders, are included in the calculated proportions of fauna belonging to each trophic group in 2012 , the results still indicate that the majority (63\%) of fauna are deposit feeders. Another $31 \%$ are suspension feeders, and $4.6 \%$ are predator/scavengers. Unfortunately, it is impossible to comment on what changes may be present between years if these species are included.

\subsection{Species not included in statistical analyses}

The results presented and discussed above concern the 11 most recognizable and reliably identified benthic megafaunal species present at HG I. Other (putative) species were also observed, though they could not be included in the results. In 2012, numerous short-tubed translucent polychaetes were observed actively feeding with their tentacles splayed (Fig. 6a). These polychaetes appeared somewhat similar to $J$. schaudinni individuals in the same images, though the size (J. schaudinni individuals were much larger) and feeding be- 


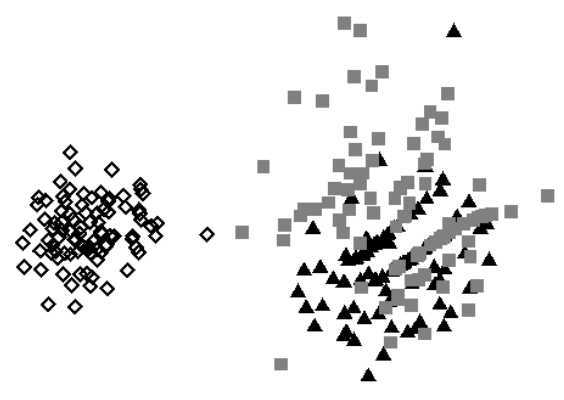

Fig. 4. Non-metric MDS plot depicting megafaunal composition in images from 2002, 2007, and 2012 at station HG I. Data have been square-root transformed. A 2-D stress value of 0.12 indicates a good fit of the data.

havior (no individuals identified as J. schaudinni were actively feeding) set the two forms apart. The two putative species are both sabellid polychaetes (N. Budaeva, personal communication, 2012). It is possible that they are both members of J. schaudinni, and it is also possible that the small, actively-feeding polychaetes belong to Chone sp., as these sabellids were caught in a trawl at HG I in 2008 (Table 2). Small, actively feeding polychaetes were not included in the 2012 results because similar individuals were not observed in other years and because it could not be determined whether or not they belonged to J. schaudinni. If these small, actively feeding individuals were included in the 2012 results for J. schaudinni, it would increase the average density for this species from $1.4 \pm 0.8 \mathrm{~m}^{-2}$ (the average reported in this study) to $6.8 \pm 0.4 \mathrm{~m}^{-2}$ (mean \pm standard error); if considered separately, they would have a density of $5.4 \pm 0.4 \mathrm{~m}^{-2}$ in 2012. We unfortunately cannot rule out the possibility that some of the "upright worm tubes" labelled from 2002 and 2007 images were in fact short, actively feeding polychaetes whose transparent tentacles were not visible.

Small white isopods, cf. Munnopsidae (Fig. 6c), were observed in images from all years sampled, but they could not be identified to higher taxonomic resolution. Despite their abundance and potentially important role in the epibenthic community, the isopods were not included in the statistical analysis because they could not be assigned to a trophic group, and because their small size meant they were more properly classified as macrofauna and were potentially subject to camera effects. Indeed, in an earlier study by Soltwedel et al. (2009), these crustaceans had been categorized as amphipods. We were not confident in the accuracy of their reported densities, as they were very difficult to detect and label accurately in the 2002 and 2007 images (K. Meyer, personal observation, 2012).

Another species, the bivalve Bathyarca frielei (Fig. 6f), was also only visible in images from 2012 because of enhanced resolution and quality of images in that year.

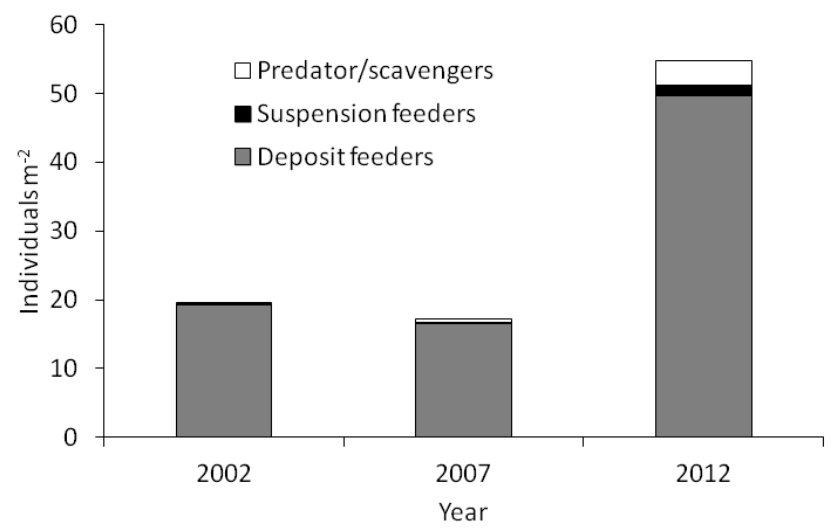

Fig. 5. Mean total density of megafauna and trophic groups in images from 2002, 2007, and 2012 at HG I (based on 11 most reliably identified taxa). Differences in density of total fauna are significant between every pair of years.

Bathyarca frielei individuals were observed burrowed halfway into the sediment and had their valves partially open as they presumably siphoned the bottom water. The resulting appearance was one of a circular or sub-circular hole in the sediment, within which the pale soft tissues of the bivalve were visible. Previously, numerous circular or sub-circular holes in the sediment had been marked in images from 2002 and 2007, and it is suspected that these structures may have been the result of marginally visible $B$. friele $i$ individuals. It should be especially noted that no circular holes in the sediment were observed in 2012 which could not be attributed to an individual of B. frielei. Upon re-examination of the 2002 and 2007 images, a few bivalve individuals could be noticed on the surface of the sediment, which could potentially also be attributed to $B$. frielei. If it is assumed that all bivalves present on the surface of the sediment and all small circular holes in the sediment in 2002 and 2007 are indeed individuals of $B$. frielei, then this species would have a population density of $10.4 \pm 0.5 \mathrm{~m}^{-2}$ in $2002,4.9 \pm 0.3 \mathrm{~m}^{-2}$ in 2007 , and $17.9 \pm 0.4$ in 2012 .

Other noteworthy habitat structures or organisms which were not included in statistical analysis because of their infrequency or lack of reliability in identification include the following (Fig. 6): a gastropod, possibly Mohnia sp., with an anemone on its shell seen in 2002; two large, oblong depressions, possibly (inactive?) pockmarks, in the seafloor in 2007; two crinoids in 2007; a ctenophore in 2007 and in 2012; a red and white superbenthic swimming isopod seen in 2012; the benthic crustacean Halirages sp., seen in 2012; and a superbenthic chaetognath seen in all years.

\subsection{Biotic habitat features}

Each of the four biotic habitat features tested showed different patterns of change in density. Tracks in the sediment (Lebensspuren) decreased from 2002 to 2012 with statistical 


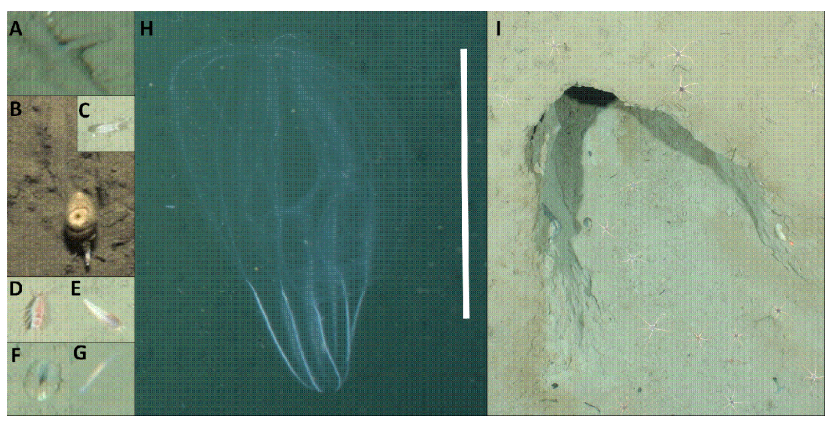

Fig. 6. Taxa observed at HG I but not included in statistical analysis. (A) sabellid polychaete; (B) gastropod, probably Mohnia sp., with anemone; (C) small white isopod, cf. Munnopsidae; (D) Halirages sp.; (E) superbenthic isopod; (F) Bathyarca frielei; (G) superbenthic chaetognath; $(\mathbf{H})$ ctenophore; (I) large depression, possibly a (inactive) pockmark. Scale bar $=10 \mathrm{~cm},(\mathbf{E}) ; 45 \mathrm{~cm},(\mathbf{G}),(\mathbf{H})$.

differences between each pair of tested years (ANOVA, $\left.F_{2,267}=184, p<0.001\right)$. There was a large increase in the frequency of "white debris," which probably consists mostly of shell fragments, in 2012 compared to in other years $\left(\mathrm{K}-\mathrm{W}, \mathrm{d} f=2, \chi^{2}=176, p<0.001\right)$. Worm tubes, both upright tubes and those lying on the sediment, were most abundant in 2012 and more frequent in 2002 than in 2007. Each pair of years tested was found to be significantly different from the others (upright worm tubes, K$\mathrm{W}, \mathrm{d} f=2, \chi^{2}=147, p<0.001$; worm tubes on sediment, $\left.\mathrm{K}-\mathrm{W}, \mathrm{d} f=2, \chi^{2}=194, p<0.001\right)$.

\subsection{Environmental and biochemical parameters}

Chloroplastic pigments in the sediment, indicating food input to the sea floor, and chlorophyll $a$, which indicates comparably "fresh" phytodetritus, show much higher values in the years 2007-2012 than in the years 2001-2006 (Fig. 7). The data suggest higher food input to the seafloor following the year 2006. Other, smaller-scale patterns can be observed, including a slight decrease in both phaeopigments and chlorophyll $a$ from 2004-2006, and a maximum in both parameters which appears in 2009. Additionally, the protein content of the sediments, indicating benthic biomass, shows a steady increase from 2001 to 2010, with particularly high values in 2007 and 2011 (Fig. 8).

\section{Discussion}

This study provides the first investigation into temporal dynamics of the benthic megafauna at the shallowest HAUSGARTEN station, HG I. We were able to identify megafauna to greater taxonomic resolution than Soltwedel et al. (2009), though it should be emphasized that the fauna of HG I are still not completely known. Some of the most recognizable taxa included in this study remain to be identified (e.g., "pur-

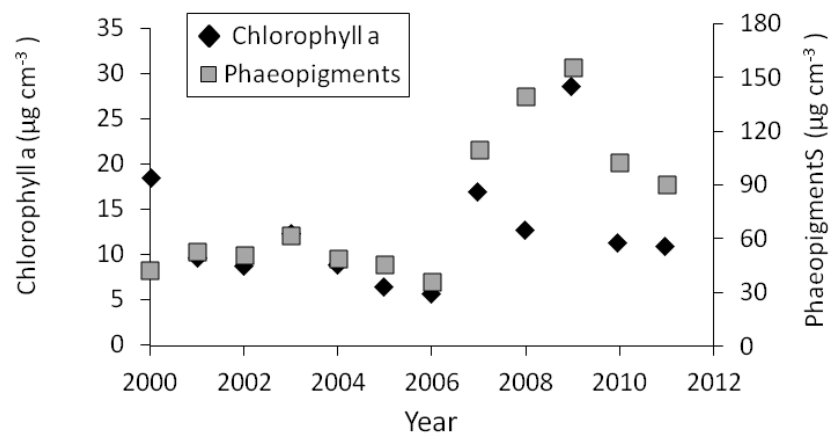

Fig. 7. Chlorophyll $a$ and phaeopigment content cumulative over the top $5 \mathrm{~cm}$ of sediment at HG I, 2001-2011.

ple cerianthid"), and additional sampling efforts will undoubtedly add new species to the station's inventory.

Despite the fact that photographic sampling was not conducted over the exact same transect location in each sampling year, we are confident that our transects are comparable and represent the same benthic megafaunal community. Transect sampling was completed at similar depths (1274-1321 m) in each year, and spatial variation in the transects was also low, as the lateral distance between the two start and end points which were furthest from each other was 5.5 nautical miles. Furthermore, the same species were observed in each year. These facts indicate that the benthic megafaunal composition varies on a spatial scale much larger than that sampled, and that the comparison of our sampled transects is justified.

\subsection{Interannual differences in megafaunal densities}

Our results indicate that benthic megafaunal dynamics are greatly influenced by biochemical condition of the sediment, which indicates food input to the seafloor. In the years leading up to 2007 , food input to the seafloor decreased slightly, as indicated by sediment-bound pigments in the top sediments. This lower phytodetrital input could explain the lower overall faunal density, in particular that of the dominant deposit-feeding ophiuroid $O$. gracilis in 2007. In the years 2007-2012, elevated levels of phytodetrital input were recorded, which is evidenced by consistently much higher chlorophyll $a$, phaeopigment, and protein content of the sediment. This elevated food input may help to explain the large increase in total megafaunal density between 2007 and 2012 . In particular, there was a higher average density of deposit feeders in 2012 than in previous years, which corresponded to significantly greater densities of $O$. gracilis and Elpidia sp. and may be attributed to higher food input.

Density of the suspension-feeding tubed polychaete $J$. schaudinni also increased significantly from 2007 to 2012, accompanied by an increase in the proportion of fauna accounted for by suspension feeders. While it is not possible to draw a direct connection between detrital food input and suspension feeder density, there may have been greater levels 
of suspended food particles in the bottom water during the time period leading up to 2012, which contributed to higher J. schaudinni population densities.

Bergmann et al. (2011b) found an overall decrease in the density of fauna between 2002 and 2007 at the nearby station HG IV ( $\sim 2500 \mathrm{~m}$ depth), which corresponds with a similar decrease in faunal density in 2007 observed in this study. In a comparison of megafaunal assemblages across a bathymetric gradient in the HAUSGARTEN area, Soltwedel et al. (2009) reported higher proportions of deposit feeders at shallower depth (i.e., HG I) and greater proportions of suspension feeders at greater depth (i.e., HG IV). This conclusion is supported by the results of the present study, in which we found great dominance of deposit feeders (>90\% of fauna) at HG I.

Food input to the seafloor has been linked to abundance and biomass of benthic fauna over latitudinal scales in the North Atlantic (Thurston et al., 1994, 1998) and temporal scales in the Pacific (Ruhl and Smith, 2004; Ruhl et al., 2008) and the Fram Strait (Bergmann et al., 2011b). Sedimentation and benthic food input are greatly influenced by productivity at the surface, and in Arctic waters, productivity is often concentrated at the ice edge (Schewe and Soltwedel, 2003; Bauerfeind et al., 2009; Hebbeln and Wefer, 1991). HG I is not usually covered by ice because of its easterly location within the Fram Strait, and examination of satellite-derived ice cover maps confirms that this is the case (K. Meyer, unpublished data). It is thus believed that ice cover and iceedge phytoplankton blooms did not significantly influence phytodetrital flux to the seafloor at HG I during the time period studied. Interestingly, differences in benthic food input reported here for HG I do not seem to be correlated with temperature anomalies or the volume of water transported into the eastern Fram Strait as reported by Beszczynska-Möller et al. (2012). Sedimentation rates also depend on multiple factors, including degradation or consumption of detritus in the water column and mesoscale hydrodynamics such as eddies (Lalande et al., 2011). Just what may have caused the higher phytodetrial input at HG I in the years following 2006 is thus an open question.

Ruhl and Smith (2004) found a 7-12 month time lag between particulate organic carbon flux to the seafloor and benthic megafaunal abundance in the northeast temperate Pacific. We sampled benthic megafauna at lower temporal resolution than Ruhl and Smith (2004), though our data also suggest the existence of a time lag between benthic food input and megafaunal abundance in the eastern Fram Strait. In particular, the lower densities of megafauna observed in 2007 can best be explained by lower food input to the seafloor in years preceding 2007 rather than the elevated food input measured in 2007.

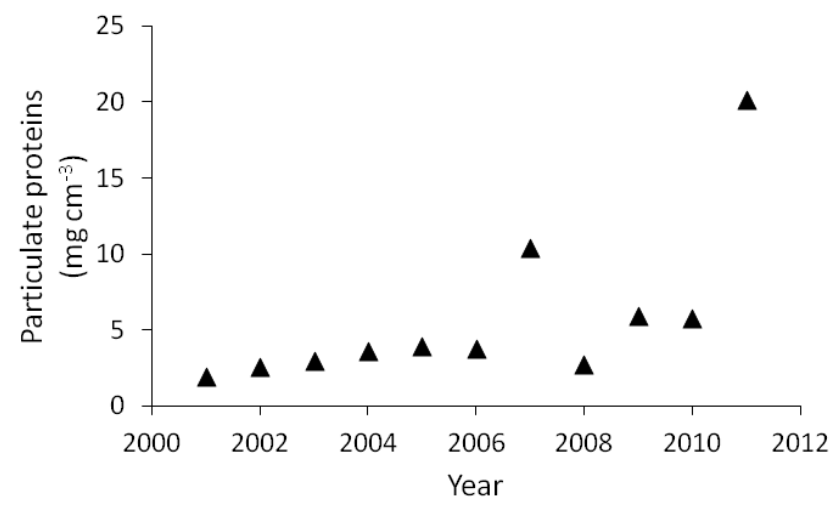

Fig. 8. Sediment-bound protein content cumulative over the top $5 \mathrm{~cm}$ of sediment at HG I, 2001-2020.

\subsection{Interannual differences in diversity and evenness}

Bergmann et al. (2011b) found lower evenness and diversity of the megafauna at HG IV in 2007 than in 2002 and 2004, which corresponded to dominance of fewer organisms and food limitation in 2007. In contrast, we found that evenness and diversity of the fauna at HG I were significantly higher than in 2007 than in 2002. Bergmann et al. (2011b) ascribed the lower evenness they observed in 2007 to disproportionate success of species with lower energy requirements in a food-limited environment; however, we cannot draw the same conclusion, as our data show the opposite relationship. The higher evenness and diversity in 2007 may be due to significantly lower densities of $O$. gracilis, which dominated the fauna in 2002. Lower food input to the seafloor may have affected recruitment, mortality, and emigration of this deposit-feeding species, thereby undermining its dominance of the epibenthic megafauna. Other deposit-feeding species (C. proboscidea, Elpidia sp.), which did not have lower density in 2007 , may not have been as strongly affected by the lower food input because their populations were already at relatively low density, and lower food input was still sufficient to sustain the population.

Both evenness and diversity were also significantly higher in 2012 than in 2007 and 2002, and we again suspect this is related to food input to the seafloor. The higher species richness (total species $\mathrm{m}^{-2}$ ) recorded in 2012 may have been merely a result of the higher total faunal density and will not be discussed further. Higher relative proportions of suspension feeders and predator/scavengers were observed in 2012. Thus, it could be argued that the megafauna of HG I became more trophically diverse. Unlike 2002 and 2007, which had only one character species $(O$. gracilis) that accounted for 94-96\% of the within-year similarity, 2012 was characterized by multiple character species. These included $O$. gracilis, cf. N. macronyx and J. schaudinni. The average density of Elpidia sp. was also much higher in 2012. Elevated levels of food input to the seafloor may have relaxed competition 
for limited resources, allowing for higher densities of multiple species through bottom-up control.

The deep sea is generally considered to be food limited (Smith et al., 2008; Iken et al., 2001). The significantly higher faunal density, diversity and evenness we observed following years of elevated food input suggest that HG I is also food limited. However, it is generally observed that food limitation in the deep sea causes low abundance but high diversity of organisms, and when food input increases, whether by natural or artificial means, one or two opportunistic species come to dominate the fauna (Smith et al., 2008). For example, in response to increased detrital flux to the seafloor, the holothurian Amperima rosea underwent greatly elevated recruitment and came to dominate the fauna of the Porcupine Abyssal Plain (Billett et al., 2010). The fact that greater diversity and evenness were associated with greater food input to the seafloor in our study may indicate uniqueness of the megafauna at HG I and an exception to the commonly accepted paradigm. In this case, continued future sampling is necessary to track patterns of change in faunal diversity with food input at HG I.

\subsection{Possible mechanisms for change in faunal density}

There are a few possible mechanisms by which populations of the benthic megafauna at HG I may have responded to changes in food availability. For deposit feeders and suspension feeders, the slight decrease in phytodetrital input to the seafloor observed in 2004-2005 (as measured by chlorophyll $a$ and phaeopigment content of the sediment) may have caused increased mortality, decreased recruitment, or caused emigration to areas of higher food supplies that lead to lower observed population densities in 2007. Conversely, the increase in phytodetrital input to the seafloor in 2007-2011 may have caused elevated recruitment or migration of individuals from adjacent areas of lower food input. The vast majority of fauna (10 of 12 species and $97-99 \%$ of individuals) at HG I are vagile, so migration could have been an important mechanism for changes in faunal density. However, for the sessile tube-building polychaete $J$. schaudinni, migration cannot explain the large increase in density from 2007-2012, so this species must have undergone elevated recruitment.

Ophiocten gracilis has an annual reproductive cycle and high fecundity (Sumida et al., 2000; Gage, 2003), so if the growth of reproductive adults was affected by food availability, this could impact reproduction. Ophiuroids are also known to occur in high densities and capitalize on favourable conditions (Metaxas and Giffin, 2004), so migration from areas of lower food availability may have contributed to their high abundance at HG I in 2012.

\subsection{Differential dynamics of species}

While some species had significantly higher or lower densities in the years sampled, the majority (6 of 11 species) showed no significant differences in density. In the case of predator/scavengers, differential dynamics of each species may be related to the dynamics of different types or species of prey. Whereas cf. N. macronyx increased in density in 2002-2012, each of the other, larger predator/scavenger species (Byglides sp., Bythocaris sp., B. vexillifer, L. squamiventer, L. flagellicauda) stayed at a constant density. The larger body size of these species compared to cf. $N$. macronyx suggests they may be feeding on different kinds of prey and their population dynamics are thus influenced by different food sources; however, further investigation along this avenue is needed before conclusions can be drawn.

The steady population densities in five of six observed predator/scavenger species may be caused by slow generation times, which restrict the population from responding quickly to changes in potential prey species. For example, the zoarcid fish Lycodes squamiventer is slow growing and longlived ( $\sim 21 \mathrm{yr}$ ) within the HAUSGARTEN area, and females of this species produce only a few $(\sim 60)$ large demersal eggs in June of each year (Hildebrandt et al., 2011).

\subsection{Biotic habitat features}

In addition to the benthic megafauna, we quantified the densities of four biotic habitat features at HG I: upright worm tubes, worm tubes lying on the sediment, Lebensspuren (tracks in the sand), and "white debris" (probably mostly shell fragments). Vertical and horizontal worm tubes were differentiated because of the different effects each would have on the texture of the sediment, surface area of the sediment available for deposit feeding, and small-scale water flows. Both upright worm tubes and those lying on the sediment had lower density in 2007 than in 2002 but much higher density in 2012. This pattern may be influenced by polychaete mortality and decomposition, destruction, or burial of worm tubes by physical factors or other fauna. Similarly, the significant increase in "white debris" observed in 2012 may have been caused by increased sedimentation or mortality of shelled organisms. Both a gastropod (cf. Mohnia sp.) and the bivalve Bathyarca frielei were observed in the images, though their densities in each year could not be quantified. Lebensspuren densities decreased between each pair of sampling years. Lower Lebensspuren density may be the result of decreased megafaunal movement or, conversely, increased megafaunal movement that lead to decreased Lebensspuren residence time (Bell et al., 2013). Unfortunately, we were unable to quantify the lengths of Lebensspuren. Vertical and horizontal worm tubes and "white debris" are all small compared to the largest megafaunal species identified from HG I. However, for small megafaunal organisms such as Bylgides $s p$. or cf. Nymphon macronyx - or perhaps also for macrofauna, which we did not sample - changes in the densities of these habitat features could be important, as these organisms experience their habitat on a small spatial scale (Quéric and Soltwedel, 2007). 


\section{Summary and conclusions}

Using a towed deep-sea camera system, we observed a decrease in the overall density of epibenthic megafauna from 2002-2007 followed by a large increase in megafaunal densities from 2007-2012 at the station HG I in the eastern Fram Strait. The relative proportions of predator/scavengers and suspension feeders increased over this time period, though the density of deposit feeders was also higher in 2012. Our results indicate that the megafaunal community is greatly influenced by food input to the seafloor as indicated by sediment-bound biochemical parameters. Evenness and diversity were significantly higher in 2012 , following years of elevated food input to the seafloor, which suggests the community at HG I is food-limited and subject to bottom-up control. The megafaunal community of HG I may be unique in its response to elevated food input that resulted in higher evenness and diversity. Also, continued sampling in the coming years with the same high-resolution camera used in 2012 would allow us to track and understand the population dynamics of species which first became visible in 2012 samples in this study.

Acknowledgements. We would like to thank the officers and crews of R/V Polarstern and R/V Maria S. Merian for their assistance at sea. M. Blume operated the OFOS in 2007. I. Schewe was responsible for deployments of the multiple corer, and he was assisted by C. Hasemann, A. Pappert, and a large number of volunteers in the analysis of biochemical parameters. The following taxonomic experts are thanked for their identifications of specimens: R. Bramber (pycnogonids, Natural History Museum, London); M. Blazewicz-Paszkowycz (Tanaidacea, University of Lodz); A. Brandt, U. Mühlenhardt-Siegel (isopods, cumaceans Universität Hamburg); S. Gromisz, M. Kedra, J. Legezynska, J. M. Weslawski (polychaetes, sipunculids, amphipods, Institute of Oceanology of the Polish Academy of Sciences); M. Türkay (decapods, Forschungsinstitut und Naturmuseum Senckenberg); P. R. Møller (fish, Zoological Museum Copenhagen); A. Peňa (hydroids, Universidad de Valencia); D. Piepenburg, (echinoderms, Universität Kiel); A. Warén (molluscs, Swedish Museum of Natural History), N. Budaeva, V. Mokievsky, A. Vedenin (polychaetes, crustaceans, bivalves, P. P. Shirshov Institute of Oceanology). T. Schoening and J. Ontrup provided user support with BIIGLE. We thank J. Gutt and an anonymous reviewer, whose comments significantly improved an earlier version of this manuscript. K. Meyer was funded by a Fulbright Study-Research Grant during the duration (July 2011-May 2012) of her tenure at the AWI. This work was part of the EU funded projects HERMES (Contract number: GOCE-CT-2005-511234-1) and HERMIONE (Contract number: 226354). This publication is Eprint ID 31642 of the Alfred Wegener Institute Helmholtz Centre for Polar and Marine Research.

Edited by: R. Danovaro

\section{References}

Afanasév, I. F.: Investigations of the deep-sea bottom fauna in the central part of the Arctic Ocean, Oceanology, 18, 950-951, 1978.

Bauerfeind, E., Nöthig, E.-M., Beszczynska-Möller, A., Fahl, K., Kaleschke, L., Kreker, K., Klages, M., Soltwedel, T., Lorenzen, C., and Wegner, J.: Particle sedimentation patterns in the eastern Fram Strait during 2000-2005: Results from the Arctic long-term observatory HAUSGARTEN, Deep-Sea Res. Pt. I, 56, 1406-1417, doi:10.1016/j.dsr.2009.04.011, 2009.

Beaulieu, S. E.: Colonization of habitat islands in the deep sea: recruitment to glass sponge stalks, Deep-Sea Res. Pt. I, 48, 11211137, 2001.

Bell, J. B., Jones, D. O. B., and Alt, C. S.: Lebensspuren of the bathyal Mid-Atlantic Ridge, Deep-Sea Res. Pt. II, in press, 2013.

Bergmann, M., Dannheim, J., Bauerfeind, E., and Klages, M.: Trophic relationships along a bathymetric gradient at the deepsea observatory HAUSGARTEN, Deep-Sea Res. Pt. I, 56, 408424, doi:10.1016/j.dsr.2008.10.004, 2009.

Bergmann, M., Langwald, N., Ontrup, J., Soltwedel, T., Schewe, I., Klages, M., and Nattkemper, T. W.: Megafaunal assemblages from two shelf stations west of Svalbard, Mar Biol Res, 7, 525539, doi:10.1080/17451000.2010.535834, 2011a.

Bergmann, M., Soltwedel, T., and Klages, M.: The interannual variability of megafaunal assemblages in the Arctic deep sea: Preliminary results from the HAUSGARTEN observatory $\left(79^{\circ} \mathrm{N}\right)$, Deep-Sea Res. Pt. I, 58, 711-722, doi:10.1016/j.dsr.2011.03.007, 2011b.

Beszczynska-Möller, A., Fahrbach, E., Schauer, U., and Hansen, E.: Variability in Atlantic water temperature and transport at the entrance to the Arctic Ocean, 1997-2010, ICES J. Mar. Sci., 69, 852-863, doi:10.1093/icesjms/fss056, 2012.

Billett, D. S. M., Bett, B. J., Rice, A. L., Thurston, M. H., Galéron, J., Sibuet, M., and Wolff, G. A.: Long-term change in the megabenthos of the Porcupine Abyssal Plain (NE Atlantic), Prog. Oceanogr., 50, 325-348, 2001.

Billett, D. S. M., Bett, B. J., Reid,W. D. K., Boorman, B., and Priede, I. G.: Long-term change in the abyssal NE Atlantic: The "Amperima Event" revisited, Deep-Sea Res. Pt. I, 57, 14061417, 2010.

Bluhm, B. A., MacDonald, I. R., Debenham, C., and Iken, K.: Macro- and megabenthic communities in the high Arctic Canada Basin: initial findings, Polar Biol., 28, 218-231, 2005.

Clarke, K. R. and Gorley, R. N.: Primer v6: User Manual/Tutorial, edited by: PRIMER-E, Plymouth, 190 pp., 2006.

Comiso, J. C., Parkinson, C. L., Gersten, R., and Stock, L.: Accelerated decline in the Arctic sea ice cover, Geophys. Res. Lett., 35, L01703, doi:10.1029/2007g1031972, 2008.

Feder, H. M. and Pearson, T. H.: The Benthic Ecology of Loch Linnhe and Loch Eil, a Sea-Loch System on the West-Coast of Scotland, 5. Biology of the Dominant Soft-Bottom Epifauna and Their Interaction with the Infauna, J. Exp. Mar. Biol. Ecol., 116, 99-134, doi:10.1016/0022-0981(88)90050-0, 1988.

Gage, J. D.: Growth and production of Ophiocten gracilis (Ophiuroidea: Echinodermata) on the Scottish continental slope, Mar Biol., 143, 85-97, doi:10.1007/s00227-003-1050-7, 2003.

Gallucci, F., Fonseca, G., and Soltwedel, T.: Effects of megafauna exclusion on nematode assemblages at a deep-sea site, Deep-Sea Res. Pt. I, 55, 332-349, doi:10.1016/j.dsr.2007.12.001, 2008a. 
Gallucci, F., Sauter, E., Sachs, O., Klages, M., and Soltwedel, T.: Caging experiment in the deep sea: Efficiency and artefacts from a case study at the Arctic long-term observatory HAUSGARTEN, J. Exp. Mar. Biol. Ecol., 354, 39-55, doi:10.1016/j.jembe.2007.10.006, 2008b.

Gamber, J. H. and Clark, D. L.: Distribution of microscopic molluscs, echinoderms and sponges in the central Arctic Ocean, Micropalaeontol., 24, 422-431, 1978.

Hasemann, C. and Soltwedel, T.: Small-scale heterogeneity in deepsea nematode communities around biogenic structures, PLoS One, 6, e29152, doi:10.1371/journal.pone.0029152, 2011.

Hebbeln, D. and Wefer, G.: Effects of ice coverage and ice-rafted material on sedimentation in the Fram Strait, Nature, 350, 409411,1991

Hildebrandt, N., Bergmann, M., and Knust, R.: Longevity and growth efficiency of two deep-dwelling Arctic zoarcids and comparison with eight other zoarcid species from different climatic regions, Polar Biol., 34, 1523-1533, doi:10.1007/s00300-0111011-4, 2011.

Hunkins, K. L., Ewing, M., Heezen, B. C., and Menzies, R. J.: Biological and geological observations on the first photographs of the Arctic Ocean deep-sea floor, Limnol. Oceanogr., 5, 154-161, 1960.

Iken, K., Brey, T., Wand, U., Voigt, J., and Junghans, P.: Food web structure of the benthic community at the Porcupine Abyssal Plain (NE Atlantic): a stable isotope analysis, Prog. Oceanogr., 50, 383-405, 2001.

Jones, D. O. B., Bett, B. J., and Tyler, P. A.: Depth-related changes in the arctic epibenthic megafaunal assemblages of Kangerdlugssuaq, East Greenland, Mar. Biol. Res., 3, 1111-1128, 2007.

Kaufmann, R. S. and Smith, K. L.: Activity patterns of mobile epibenthic megafauna at an abyssal site in the eastern North Pacific: results from a 17-month time-lapse photographic study, Deep-Sea Res. Pt. I, 44, 559-579, 1997.

Kauker, F., Kaminski, T., Karcher, M., Giering, R., Gerdes, R., and Voßbeck, M.: Adjoint analysis of the 2007 all time Arctic sea-ice minimum, Geophys. Res. Lett., 36, L03707, doi:10.1029/2008g1036323, 2009.

Lalande, C., Bauerfeind, E., and Nöthig, E. M.: Downward particulate organic carbon export at high temporal resolution in the eastern Fram Strait: influence of Atlantic Water on flux composition, Mar. Ecol.-Prog. Ser., 440, 127-136, doi:10.3354/meps09385, 2011.

MacDonald, I. R., Bluhm, B. A., Iken, K., Gagaev, S., and Strong, S.: Benthic macrofauna and megafauna assemblages in the Arctic deep-sea Canada Basin, Deep-Sea Res. Pt. I, 57, 136-152, doi:10.1016/j.dsr2.2009.08.012, 2010.

Mayer, M. and Piepenburg, D.: Epibenthic community patterns on the continental slope off East Greenland at $75^{\circ}$ N, Mar. Ecol.Prog. Ser., 143, 151-164, 1996.

Metaxas, A. and Giffin, B.: Dense beds of the ophiuroid Ophiacantha abyssicola on the continental slope off Nova Scotia, Canada, Deep-Sea Res. Pt. I, 51, 1307-1317, doi:10.1016/j.dsr.2004.06.001, 2004.

Ontrup, J., Ehnert, N., Bergmann, M., and Nattkemper, T. W.: Biigle - Web 2.0 enabled labelling and exploring of images from the Arctic deep-sea observatory HAUSGARTEN, OCEANS 2009 EUROPE, doi:10.1109/OCEANSE.2009.5278332, 2009
Paul, A. Z. and Menzies, R. J.: Benthic ecology of the high arctic deep sea, Mar. Biol., 27, 251-262, 1974.

Pielou, E. C.: An introduction to mathematical ecology, Wiley, New York, 286 pp., 1969.

Piepenburg, D., Blackburn, T. H., Vondorrien, C. F., Gutt, J., Hall, P. O. J., Hulth, S., Kendall, M. A., Opalinski, K. W., Rachor, E., and Schmid, M. K.: Partitioning of Benthic Community Respiration in the Arctic (Northwestern Barents Sea), Mar. Ecol.-Prog. Ser., 118, 199-213, 1995.

Piepenburg, D., Chernova, N. V., von Dorrien, C. F., Gutt, J., Neyelov, A. V., Rachor, E., Saldanha, L., and Schmid, M. K.: Megabenthic communities in the waters around Svalbard, Polar Biol., 16, 431-446, 1996a.

Piepenburg, D., Chernova, N. V., vonDorrien, C. F., Gutt, J., Neyelov, A. V., Rachor, E., Saldanha, L., and Schmid, M. K.: Megabenthic commmunities in the waters around Svalbard, Polar Biol., 16, 431-446, 1996 b.

Piepenburg, D.: Recent research on Arctic benthos: common notions need to be revised, Polar Biol., 28, 733-755, doi:10.1007/s00300-005-0013-5, 2005.

Quéric, N.-V. and Soltwedel, T.: Impact of small-scale biogenic sediment structures on bacterial distribution and activity in Arctic deep-sea sediments, Mar. Ecol.-Evol. Persp., 28, 66-74, 2007.

Ruhl, H. A. and Smith Jr., K., L.: Shifts in Deep-Sea Community Structure Linked to Climate and Food Supply, Science, 305, 513 515, doi:10.1126/science.1099759, 2004.

Ruhl, H. A., Ellena, J. A., and Smith, K. L.: Connections between climate, food limitation, and carbon cycling in abyssal sediment communities, Proc. Natl. Acad. Sci., 105, 17006-17011, doi:10.1073/pnas.0803898105, 2008.

Sardá, R., Foreman, K., Werme, C. E., and Valiela, I.: The impact of epifaunal predation on the structure of macroinfaunal invertebrate communities of tidal saltmarsh creeks, Estuar Coast Shelf S., 46, 657-669, doi:10.1006/ecss.1997.0322, 1998.

Schewe, I. and Soltwedel, T.: Benthic response to ice-edge-induced particle flux in the Arctic Ocean, Polar Biol, 26, 610-620, doi:10.1007/s00300-003-0526-8, 2003.

Schoening, T., Bergmann, M., Ontrup, J., Taylor, J., Dannheim, J., Gutt, J., Purser, A., and Nattkemper, T. W.: Semi-Automated Image Analysis for the Assessment of Megafaunal Densities at the Arctic Deep-Sea Observatory HAUSGARTEN, Plos One, 7, e38179, doi:10.1371/journal.pone.0038179, 2012.

Schulz, M., Bergmann, M., von Juterzenka, K., and Soltwedel, T.: Colonisation of hard substrata along a channel system in the deep Greenland Sea, Polar Biol., 33, 1359-1369, 2010.

Shannon, C. E. and Weaver, W.: The mathematical theory of communication, University of Illinois Press, Urbana, Illinois, 144 pp., 1963.

Shuman, F. R. and Lorenzen, C. J.: Quantitative Degradation of Chlorophyll by a Marine Herbivore, Limnol. Oceanogr., 20, 580586, 1975.

Smith, C. R., De Leo, F. C., Bernardino, A. F., Sweetman, A. K., and Martinez Arbizu, P.: Abyssal food limitation, ecosystem structure, and climate change, Trends Ecol. Evol., 23, 518-528, doi:10.1016/j.tree.2008.05.002, 2008.

Soltwedel, T. and Vopel, K.: Bacterial abundance and biomass in response to organism-generated habitat heterogeneity in deepsea sediments, Mar. Ecol. Prog. Ser., 219, 291-298, 2001. 
Soltwedel, T., Bauerfeind, E., Bergmann, M., Budaeva, N., Hoste, E., Jaeckisch, N., Von Juterzenka, K., Matthiessen, J., Mokievsky, V., Nöthig, E.-M., Quéric, N.-V., Sablotny, B., Sauter, E., Schewe, I., Urban-Malinga, B., Wegner, I., WlodarskaKowalczuk, M., and Klages, M.: HAUSGARTEN: Multidisciplinary investigations at a deep-sea, long-term observatory in the Arctic Ocean, Oceanography, 18, 46-61, 2005.

Soltwedel, T., Jaeckisch, N., Ritter, N., Hasemann, C., Bergmann, M., and Klages, M.: Bathymetric patterns of megafaunal assemblages from the arctic deep-sea observatory HAUSGARTEN, Deep-Sea Res. Pt. I, 56, 1856-1872, doi:10.1016/j.dsr.2009.05.012, 2009.

Starmans, A. and Gutt, J.: Mega-epibenthic diversity: a polar comparison, Mar. Ecol.-Prog. Ser., 225, 45-52, doi:10.3354/meps225045, 2002.
Sumida, P. Y. G., Tyler, P. A., Lampitt, R. S., and Gage, J. D.: Reproduction, dispersal, and settlement of the bathyal ophiuroid Ophiocten gracilis in the NE Atlantic Ocean, Mar. Biol., 137, 623-630, 2000.

Thurston, M. H., Bett, B. J., Rice, A. L., and Jackson, P. A. B.: Variations in the Invertebrate Abyssal Megafauna in the NorthAtlantic Ocean, Deep-Sea Res. P.t I, 41, 1321-1348, 1994.

Thurston, M. H., Rice, A. L., and Bett, B. J.: Latitudinal variation in invertebrate megafaunal abundance and biomass in the North Atlantic Ocean Abyss, Deep-Sea Res. Pt. I, 45, 203-224, 1998.

Wheatcroft, R. A., Smith, C. R., and Jumars, P. A.: Dynamics of Surficial Trace Assemblages in the Deep-Sea, Deep-Sea Res. Pt. I, 36, 71-91, 1989. 